\title{
Immune checkpoint receptors in regulating immune reactivity in rheumatic disease
}

\author{
Sabrina Ceeraz ${ }^{1 *}$, Elizabeth C Nowak' ${ }^{1}$ Christopher M Burns ${ }^{2}$ and Randolph J Noelle $e^{1,3,4^{*}}$
}

\begin{abstract}
Immune checkpoint regulators are critical modulators of the immune system, allowing the initiation of a productive immune response and preventing the onset of autoimmunity. Co-inhibitory and co-stimulatory immune checkpoint receptors are required for full T-cell activation and effector functions such as the production of cytokines. In autoimmune rheumatic diseases, impaired tolerance leads to the development of diseases such as rheumatoid arthritis, systemic lupus erythematosus, and Sjogren's syndrome. Targeting the pathways of the inhibitory immune checkpoint molecules CD152 (cytotoxic T lymphocyte antigen-4) and CD279 (programmed death-1) in cancer shows robust anti-tumor responses and tumor regression. This observation suggests that, in autoimmune diseases, the converse strategy of engaging these molecules may alleviate inflammation owing to the success of abatacept (CD152-lg) in rheumatoid arthritis patients. We review the preclinical and clinical developments in targeting immune checkpoint regulators in rheumatic disease.
\end{abstract}

\section{Introduction}

Rheumatic diseases include inflammatory disorders that cause pain, inflammation, or damage in joints and other organs, resulting in significant morbidity, mortality, and societal costs. Examples that are felt to be the result of autoimmunity include rheumatoid arthritis (RA), juvenile idiopathic arthritis (JIA), systemic lupus erythematosus (SLE), psoriasis, systemic sclerosis (SSc), and Sjogren's syndrome (SS). The magnitude of an inflammatory response is

\footnotetext{
* Correspondence: sabrina.c.delong@dartmouth.edu; rjn@dartmouth.edu 'Department of Microbiology and Immunology, Norris Cotton Cancer Center, Geisel School of Medicine at Dartmouth, 1 Medical Center Drive, Lebanon, $\mathrm{NH}$ 03756, USA

${ }^{3}$ Medical Research Council Centre of Transplantation, Guy's Hospital, King's College London, London SE1 9RT, UK

Full list of author information is available at the end of the article
}

the net result of molecular pathways that enhance or temper immunity. Both genetic and environmental factors control these pathways and can influence the development and severity of these diseases. Beyond engagement of the innate immune system, the perpetuation and amplification of these pathologic processes requires signaling through the B-cell or T-cell receptor, followed by subsequent ligand interactions delivering co-stimulatory and/or coinhibitory signals. These secondary signals are critical in determining cellular effector functions and modulating immunity to maintain homeostasis [1]. Co-stimulatory and co-inhibitory molecules belong to the B7/B7 ligand family and the tumor necrosis factor (TNF)/TNF receptor family. Their expression and functions are summarized in Tables 1 and 2 .

The ability to interfere with the inhibitory function of checkpoint receptors CD152 (cytotoxic T lymphocyte antigen-4) and CD279 (programmed death-1) in oncology has proved successful. In 2011 the US Food and Drug Administration (FDA) approved ipilimumab, an $\alpha \mathrm{CD} 152$ monoclonal antibody $(\mathrm{Ab})$, for use in the clinic. In patients with metastatic melanoma, ipilimumab was found to effectively prolong survival and reduce metastases $[8,9]$. Manipulating the CD279 pathway has been shown to have remarkable efficacy in cancer patients. In patients with melanoma, nonsmall cell lung cancer, and renal cell carcinoma, treatment with BMS-936558, a CD279 blocking Ab, promoted anti-tumor responses [8]. Similarly, CT-011 (Cure Tech Ltd, Yavne, Israel), a humanized $\alpha \mathrm{CD} 279 \mathrm{IgG}_{1}$ monoclonal Ab, safely induced remission in a subset of patients with hematologic malignancies [8]. In patients with solid cancers, tumor regression was noted following therapy with MDX-1106 (Medarex, Princeton, NJ, USA), an $\alpha$ CD279 IgG4 Ab, further demonstrating that the CD279 pathway plays a crucial role in cancer progression [2]. In addition to targeting $\mathrm{CD} 279$, there are ongoing phase 1 clinical trials investigating the role of CD279 ligands: CD274/programmed death ligand (PD-L)-1 in patients with solid tumors [ClinicalTrials.gov:NCT00729664] and CD273/PD-L2 in stage IV 
Table 1 B7/B7 ligand family members and functions

\begin{tabular}{|c|c|c|c|}
\hline Molecule & Expression & Ligand/receptor & Function \\
\hline \multirow[t]{3}{*}{ CD28 } & Resting T cells & CD80 or CD86 on APCs & Lowers TCR threshold \\
\hline & & & Delivers a co-stimulatory signal \\
\hline & & & $\begin{array}{l}\text { Promotes T-cell proliferation, survival, } \\
\text { cytokine production, T cell- } \\
\text { dependent B cell functions [2] }\end{array}$ \\
\hline \multirow[t]{4}{*}{ CTLA-4/CD152 } & Resting/activating T cells & $\begin{array}{l}\text { Outcompetes CD28 for CD80/CD86 } \\
\text { binding }\end{array}$ & Increased TCR threshold \\
\hline & & & Delivers a co-inhibitory signal [2] \\
\hline & & & $\begin{array}{l}\text { Upregulates indoleamine } \\
\text { 2,3-dioxygenase }\end{array}$ \\
\hline & & & $\begin{array}{l}\mathrm{CTLA}-4^{-/-} \text {mice develop } \\
\text { autoimmunity [2] }\end{array}$ \\
\hline \multirow[t]{2}{*}{ PD-1/CD279 } & $\begin{array}{l}\text { T cells, B cells, DCs, monocytes, NK T } \\
\text { cells, exhausted cells and Tregs }\end{array}$ & $\begin{array}{l}\text { PD-L1 on APCS, B cells, and T cells. } \\
\text { PD-L2/CD273 on APCs. PD-L1/CD274 } \\
\text { can also bind to CD80 }\end{array}$ & Delivers an inhibitory signal \\
\hline & & & Suppresses Bcl-xl [2] \\
\hline \multirow[t]{3}{*}{ ICOS/CD278 } & Activated T cells, T follicular helper cells & ICOSL/CD275 on APCs and B cells [2] & Induces proliferation \\
\hline & & & Propagates germinal center reactions \\
\hline & & & Upregulates IL-10 production [2] \\
\hline BTLA/CD272 & B cells, DCs, Th1 cells, macrophages & Herpes virus entry mediator [2] & $\begin{array}{l}\text { BTLA delivers an inhibitory signal via } \\
\text { ITIM and ITSM [2] }\end{array}$ \\
\hline $\mathrm{B} 7-\mathrm{H} 3 / \mathrm{CD} 276$ & $\begin{array}{l}\text { B cells, NK cells, T cells, activated } \\
\text { monocytes [2] }\end{array}$ & Unknown & $\begin{array}{l}\text { Co-inhibitory and co-stimulatory } \\
\text { functions. Suppress antitumor re- } \\
\text { sponses [2] }\end{array}$ \\
\hline B7-H4/B7S1/B7x/Nten1 & $\begin{array}{l}\text { APCs, cancer cells, and mRNA expression } \\
\text { on nonhematopoietic tissue [2] }\end{array}$ & Unknown & $\begin{array}{l}\text { Reduces cell proliferation and T cell } \\
\text { interleukin-2 production [2] }\end{array}$ \\
\hline $\mathrm{B} 7-\mathrm{H} 6$ & Tumor cells [3] & NKp30 & $\begin{array}{l}\text { Binds NKp30 on NK cells resulting in } \\
\text { interferon gamma and cytotoxic } \\
\text { function [2] }\end{array}$ \\
\hline \multirow[t]{2}{*}{ VISTA/Dies1/Gi24/PD-1H } & $\begin{array}{l}\text { Highly expressed on murine myeloid } \\
\text { cells. Low expression on T cells [2] }\end{array}$ & Unknown & $\begin{array}{l}\text { Inhibits T-cell proliferation, reduces } \\
\text { CD44 and CD69 expression [2] }\end{array}$ \\
\hline & & & Increases cell motility [2] \\
\hline
\end{tabular}

APC, antigen presenting cell; BTLA, B and T lymphocyte attenuator; CTLA-4, cytotoxic T lymphocyte antigen-4; DC, dendritic cell; ICOS, inducible co-stimulator; ICOSL, inducible co-stimulator ligand; ITIM, immunoreceptor tyrosine-based inhibition motif; ITSM, immunoreceptor tyrosine-based switch motif; NK, natural killer; PD-1, programmed death-1; PD-L, programmed death ligand; TCR, T-cell receptor; Th, T helper; Treg, regulatory T cell.

melanoma patients [ClinicalTrials.gov:NCT00658892]. The successes in manipulating CD152 and CD279/CD279 ligands in cancer provide proof of concept that targeting these molecules can have profound effects on the human immune response [8].

In contrast to the cancer studies, delivering an inhibitory signal or blocking a stimulatory signal to achieve endogenous immunosuppression is critical in autoimmune diseases. This was first shown in 2005 when the FDA approved the humanized fusion protein CD152-IgG 1 (abatacept) as a treatment for RA [10]. The aim of this review is to discuss the function of co-stimulatory and co-inhibitory molecules in the pathogenesis of SLE, RA, JIA, SS, psoriasis, and SSc, as well as their potential use as therapeutic targets.

\section{Systemic lupus erythematosus}

SLE is a chronic inflammatory disease targeting multiple organs including the skin, joints, kidneys, lungs, and central nervous system. During disease, autoantibodies to a spectrum of self-antigens, including nuclear antigens, develop and form immune complexes in various tissues. In the kidneys this complex formation results in glomerulonephritis (GN) [11-13]. Current therapies in SLE focus on both B-cell and T-cell targets. The $\alpha \mathrm{CD} 20 \mathrm{Ab}$ rituximab (Genentech, South San Francisco, CA, USA) has been effective anecdotally, but failed to achieve significant benefit above background therapy in separate clinical trials of nonrenal and renal SLE [14,15]. However, it is now thought that these trials may have failed because the high dosage of glucocorticoids used could have masked the 
Table 2 Tumor necrosis factor/tumor necrosis factor receptor family members and functions

\begin{tabular}{|c|c|c|c|}
\hline Molecule & Expression & Ligand/receptor & Function \\
\hline DR3 & Lymphocytes & $\begin{array}{l}\text { Tumor necrosis factor-like cytokine 1A (TL1A) } \\
\text { expressed on APCs [4] }\end{array}$ & $\begin{array}{l}\text { Delivers a co-inhibitory signal, induces cell } \\
\text { survival, prevents apoptosis }[4,5]\end{array}$ \\
\hline \multirow[t]{2}{*}{ 4-1BB/CD137 } & $\begin{array}{l}\text { Activated T cells, Tregs, DCs and } \\
\text { B cells }\end{array}$ & 4-1BB ligand on DCs and B cells [6] & $\begin{array}{l}\text { 4-1BB induces CD8 }{ }^{+} \text {T-cell, NK T-cell and B-cell } \\
\text { survival [6] }\end{array}$ \\
\hline & & & $\begin{array}{l}\text { Signaling back via 4-1BB ligand induces monocyte } \\
\text { activation [6] }\end{array}$ \\
\hline \multirow[t]{2}{*}{ OX40/CD134 } & Activated T cells & $\begin{array}{l}\text { OX40 ligand/CD252 on B cells, endothelial } \\
\text { cells, DCs and macrophages }\end{array}$ & $\begin{array}{l}\text { OX40 increases CD4 }{ }^{+} \text {T-cell survival/effector } \\
\text { function [6] }\end{array}$ \\
\hline & & & $\begin{array}{l}\text { OX40 impacts immunoregulation by reducing } \\
\text { interleukin-10 production by } \operatorname{Tr} 1 \text { and } C D 4^{+} \\
\text {Tregs [6] }\end{array}$ \\
\hline \multirow[t]{2}{*}{ CD27 } & $\begin{array}{l}\text { Naïve T-cells, memory B cells, } \\
\text { NK T cells, NK cells [6] }\end{array}$ & CD70 on activated lymphocytes and DCs & $\begin{array}{l}\text { CD27-CD70 signaling on B cells propagates } \\
\text { germinal center formation and plasma cell } \\
\text { activities }\end{array}$ \\
\hline & & & $\begin{array}{l}\text { Signaling on T cells results in proliferation and } \\
\text { cytokine production [6] }\end{array}$ \\
\hline
\end{tabular}

CD154/CD40 ligand on T cells, T follicular helper cells, endothelial and epithelial cells, B cells or APCs [7]
CD154 ${ }^{+} \mathrm{T}$ cells permit germinal center formation

\author{
Signaling via CD40 on B cells induces B-cell \\ differentiation, isotype switching and \\ proliferation [7] \\ Signaling via CD40 on APCs, increases CD80 \\ and CD86 expression [7]
}

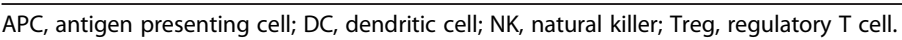

effect of rituximab [16,17]. In addition, drug efficacy is hindered by the lack of a definitive target antigen, impaired $\mathrm{T}$-cell homeostasis by reduced $\mathrm{CD} 4^{+}$regulatory $\mathrm{T}$-cell function, an altered $\mathrm{T}$-cell repertoire that in turn promotes autoantibody synthesis [18], inflammation driven by $\mathrm{T}$ helper (Th) 1 and Th2 responses [19], and soluble mediators such as interferon (IFN) alpha [20].

Positive co-stimulation through CD28 and negative regulation through CD152 are a major focus in designing immunotherapeutic agents to treat lupus patients. There is a wealth of evidence in murine models identifying interactions between CD28 and CD152 and their receptors, CD80 and CD86, as attractive clinical targets. In the spontaneous lupus-prone murine model NZBWF-1, where females develop fatal GN, CD152-Ig therapy effectively reduces autoantibody production [21]. In combination with cyclophosphamide, CD152-Ig effectively reverses nephritis and prolongs survival in NZBWF-1 mice [22]. Furthermore, prenephritic mice treated with CD152-Ig and $\alpha C D 154 \mathrm{Ab}$ have delayed disease onset and reduced anti-double-stranded DNA Abs [23]. Administered as a triple therapy combining CD152-Ig, cyclophosamide, and $\alpha \mathrm{CD} 154 \mathrm{Ab}$, prolonged remission and the presence of renal type II activated macrophages that serve as a biomarker of remission have been noted in this model [24]. In contrast to the success of CD152-Ig in murine studies, the humanized CD152-IgG 1 fusion protein abatacept has been disappointing in the clinic due to an increase in serious adverse events found in a subset of patients in a phase IIb study [25]. A clinical trial investigating the efficacy of the combination of abatacept and cyclophosamide in human lupus nephritis is ongoing [ClinicalTrials.gov:NCT00774852].

There are several other observations that the CD28CD152 axis is involved in the pathogenesis of lupus. Elevated levels of soluble CD28 are found in serum from lupus patients, which can inhibit T-cell proliferation in vitro [26]. Whether these levels are active in tempering disease is unknown. There is also an association between polymorphisms in the CD152 gene and SLE susceptibility in some ethnic groups [27]. How this polymorphism impacts disease progression is unclear because CD152 expression itself does not appear to be aberrant in SLE patients. However, studies have shown that CD152 may be functionally impaired in SLE, perhaps as a result of $\alpha C D 152$ autoantibodies [28]. Recently, one study has suggested that abatacept might be linked to regulatory T-cell repopulation [29]. Expression of CD152 ligands also appears to be relevant in SLE. High CD80 expression on $\mathrm{CD}_{4}^{+} \mathrm{T}$ cells correlates with disease severity [30], and treatment with $\alpha$ CD80 Ab reduces disease severity in the pristine-induced murine model of disease [31].

The CD278 (inducible co-stimulator)-CD275 (inducible co-stimulator ligand) co-stimulatory pathway may play a role in SLE pathogenesis. In SLE patients, CD278 is expressed on renal lymphocytes and peripheral blood 
T cells whereas CD275 is highly expressed on B cells but reduced on memory $B$ cells, possibly due to recent interactions with $\mathrm{CD}_{278^{+}} \mathrm{T}$ cells [32,33]. In vitro, CD278 and CD3 stimulation leads to increased autoantibody synthesis from SLE peripheral blood mononuclear cells, indicating that $\mathrm{CD} 278$ contributes to disease and perturbed B-cell Ab responses [34]. This is further supported in vivo by reduced autoantibody production by CD278 ${ }^{-/-}$lupus-prone MRL/lpr mice [35]. In NZBWF1 mice, prophylactic and therapeutic treatment with $\alpha C D 275$ Ab significantly reduced disease pathology [36], indicative that both the receptor and ligand are involved in perpetuating inflammation. The role of CD278 as a therapeutic target in human SLE is currently being evaluated in a phase Ib trial with AMG557, an $\alpha \mathrm{CD} 275 \mathrm{Ab}$ [ClinicalTrials.gov:NCT00774943].

CD279 is an inhibitory receptor expressed on activated $\mathrm{T}$ cells that upon binding to CD274 (PD-L1) or CD273 (PD-L2) delivers a negative signal into the T cells [37]. In SLE patients, polymorphisms in the CD279 gene are associated with disease susceptibility [38]. In vivo, the role of CD279 is evident by the development of GN in CD279 ${ }^{-/-}$ mice bred onto the lupus-prone strain lpr/lpr [39]. In NZBWF-1 mice, CD274 blockade increases $C D 4^{+} \mathrm{CD} 279^{+}$ $T$ cells and clinical pathology, demonstrating that blockade of the CD279:CD274 axis exacerbates disease [40]. In contrast, one study showed that $\alpha \mathrm{CD} 279 \mathrm{Ab}$ treatment is associated with increases in $\mathrm{CD}^{+}$and $\mathrm{CD} 4^{+}$regulatory $\mathrm{T}$ cells and protection from disease in NZBWF-1 mice $[41,42]$. Because of these contradictory results, how the CD279 pathway signals in SLE remains unknown. One explanation is that the $\alpha \mathrm{CD} 274 \mathrm{Ab}$ acted as a blocking $\mathrm{Ab}$, which in turn would explain the increase in effector $\mathrm{CD} 279^{+} \mathrm{CD} 4^{+} \mathrm{T}$ cells that produce IFN $\gamma$ and perpetuate disease [40]. It is also possible that $\alpha \mathrm{CD} 279$ $\mathrm{Ab}$ may delete $\mathrm{CD} 279^{+}$effector T cells, resulting in disease remission.

CD154 and its receptor, CD40, regulate both humoral and cellular immunity. $\mathrm{CD} 154^{+}$activated $\mathrm{T}$ cells can trigger B-cell activation, germinal center formation, long-lived $\mathrm{Ab}$ responses, and dendritic cell activation to facilitate the development of $\mathrm{CD}^{+}$and $\mathrm{CD} 8^{+}$T-cell responses [7]. Blocking this central co-stimulatory signal is an attractive target in lupus. An increase in CD154 expression on SLE lymphocytes correlates with disease severity in pediatric patients [43]. In active SLE, CD154 is highly expressed on lymphocytes and diminished in remission patients [44]. In a separate study, CD154 expression on T cells was found to induce CD80 on B cells, thus increasing their activation status and further propagating disease [45]. High levels of soluble CD154 have been detected in the serum of patients with advanced disease [46]. In vivo, $\alpha \mathrm{CD} 154 \mathrm{Ab}$ therapy in NZBWF-1 mice prevents the onset of GN [47] and, when administered prior to the establishment of $\mathrm{GN}$, diminishes renal immune complex deposition and prolongs survival [48]. Therapeutic intervention with $\alpha \mathrm{CD} 154 \mathrm{Ab}$ in this disease model also reduces disease severity and resolves proteinuria [48].

In spite of the success of $\alpha \mathrm{CD} 154 \mathrm{Ab}$ in murine models, the results of treatment in clinical trials are inconclusive [49]. In patients with active SLE, treatment with IDEC-131, a humanized $\alpha C D 154 \mathrm{Ab}$, did not significantly improve disease scores or suppress anti-doublestranded DNA Ab or complement consumption [49]. However, this finding is confounded by the high placebo response in this trial due to the heterogeneity of SLE [49]. In a phase II trial in patients with proliferative lupus nephritis, BG9588 (Biogen, Inc., Cambridge, MA, USA), another $\alpha \mathrm{CD} 154 \mathrm{Ab}$, ameliorated disease activity, including proteinuria, and diminished $\mathrm{CD} 38^{+} \mathrm{Ab}$-secreting cells [50]. Unfortunately, hematuria and thromboembolic events were reported in two subjects leading to concerns over the safety of targeting CD154 and to early termination of the trial [51]. Later studies have since reported that $\alpha \mathrm{CD} 154 \mathrm{Ab}$ contributes to atherosclerosis and prothrombotic events [52]. This has prompted the reengineering of $\alpha \mathrm{CD} 154 \mathrm{Ab}$ for safe use in SLE preclinical trials. Recently, researchers have shown that an $\alpha \mathrm{CD} 154$ $\mathrm{Ab}$ containing a mutation in the IgG1 domain impairs Fc effector function and reduces thromboembolism in NZBWF-1 mice [53]. This observation suggests that further development of the $\alpha \mathrm{CD} 154$ Abs with these modifications could increase their safety.

CD134 (OX40), a member of the TNF receptor superfamily, is a co-stimulatory molecule expressed on activated $\mathrm{T}$ cells and has been examined in SLE. CD134 expression on peripheral blood $\mathrm{T}$ cells from patients with lupus nephritis correlates with disease severity [30]. In the glomerular wall of lupus nephritis patients, CD134 expression on T cells and CD252 (OX40 ligand) expression on renal cells have been reported [54]. To understand the function of these molecules, in vitro assays have been performed to examine the function of both CD134 and CD252. For example, treatment of splenocytes from lupusprone BXSB mice with $\alpha \mathrm{CD} 252 \mathrm{Ab}$, in combination with CD152-Ig, suppresses autoantibody production and proinflammatory cytokines [55]. Similarly, in vitro treatment of peripheral blood mononuclear cells from SLE patients with an $\alpha \mathrm{CD} 134 \mathrm{Ab}$ reduces interleukin (IL)-4 and IL-10 and enhances IFNy production whereas CD134-Ig reduces both Th1 and Th2 cytokines [56]. The method of targeting CD134 can exert different outcomes and warrants further investigation. For example, $\alpha C D 134$ Ab controls inflammation in lymph nodes while CD134-Ig prevented the onset of GN [56]. Collectively, these studies show that the CD134-CD252 pathway is involved in regulating inflammation by reducing the production of cytokines such as IL-4 and IL-10, known to perpetuate inflammation in SLE. 
To date, no clinical trials targeting the CD134 pathway have been conducted.

The CD70-CD27 and CD137 (4-1BB)-CD137 ligand (4-1BB ligand) co-stimulatory pathways belong to the TNF/TNF receptor family and signal on activated T cells. In SLE patients, impaired DNA methylation of CD70 on $T$ cells is associated with disease progression [57] and expression of CD27 on memory SLE B cells and plasma cells correlates with disease severity $[58,59]$. At present, the CD70-CD27 pathway has yet to be extensively examined in murine lupus models. Several in vivo studies have investigated the role of CD137-CD137 ligand in SLE. $\mathrm{CD} 137^{-/-}$mice bred on a MRL/lpr background have increased autoantibody production, pathogenic $\mathrm{T}$ cells, and reduced survival [60]. Additionally, treatment of MRL/lpr mice with $\alpha \mathrm{CD} 137 \mathrm{Ab}$ reduced $\mathrm{CD} 4^{+} \mathrm{T}$ cells, GN, and germinal center formation, as well as prolonging survival [61]. Similarly, $\alpha$ CD137 Ab therapy reduces disease severity in the NZBWF-1 model [62]. No clinical trials have been reported with either pathway in SLE.

\section{Rheumatoid arthritis}

RA is a chronic systemic inflammatory disease characterized by destructive synovitis that, left undiagnosed, results in significant pain, deformity, and disability. RA predominately manifests in females and affects about $0.24 \%$ of the population [63]. Tissue inflammation and damage is mediated through several cell types, including $\mathrm{T}$ cells, B cells, monocytes, macrophages, and osteoclasts. Treatment of RA has been revolutionized by the use of biologics, including TNF inhibitors, rituximab, abatacept, and others beyond standard therapy, generally consisting of methotrexate.

One of the main pathways examined in RA involves CD28 and CD152 interactions with their binding partners, CD80 and CD86. Certain CD152 polymorphisms are associated with an increased risk of developing RA [64]. Soluble CD152 expression also correlates with disease severity, and membrane expression of CD152 on regulatory $\mathrm{T}$ cells is reduced $[65,66]$. Abatacept is effective in treating disease alone or in combination with methotrexate. Patients with low baseline levels of $\mathrm{CD} 8^{+} \mathrm{CD} 28^{-} \mathrm{T}$ cells are more likely to achieve full remission when treated with abatacept [67]. Additionally, the frequency of CD4 ${ }^{+} \mathrm{CD} 28^{-} \mathrm{T}$ cells decreases with treatment but it is uncertain whether this is a direct effect [68].

Other inhibitory B7 family members are also relevant in RA. CD279 polymorphisms are associated with increased susceptibility to disease, and soluble and membrane expression of CD279 is decreased in RA patients [69,70]. In mouse RA models, deficiency of CD279 or CD274 exacerbated disease [71,72]. Furthermore, treatment of mice with a CD274-Ig fusion protein marginally attenuates collagen-induced arthritis (CIA) [73]. High levels of soluble B7-H4, a B7 family inhibitory ligand, are associated with disease severity in RA patients as well as in murine models [74,75]. Both deficiency of B7$\mathrm{H} 4$ and transgenically increased soluble expression of B7-H4 in CIA leads to accelerated disease, and treatment with a B7-H4-Ig fusion protein attenuates CIA [75]. AMP-110, a B7-H4-Ig fusion protein, is currently in a phase I study for use in RA [ClinicalTrials.gov: NTC01878123]. Co-inhibitory ligand CD272 (BTLA) and its receptor HVEM are found in affected synovium of RA patients [76,77]. Treatment of mice with HVEM-Ig increased disease severity in CIA [78]. No clinical trials involving BTLA and HVEM have been documented in RA.

The CD40 and CD154 pathway is implicated in RA pathogenesis. Some CD40 gene polymorphisms are associated with increased RA susceptibility. In addition, CD154 expression is increased in blood and synovial fluid $\mathrm{T}$ cells from RA patients [79,80]. IgM and IgG Abs against rheumatoid factor also correlate with increased levels of soluble CD154 [81]. Females with disease have greater expression of CD154 on CD4 T cells in comparison with healthy female controls, and the CD154 promoter is hypomethylated in females, but not males, with RA [82]. In CIA, $\alpha C D 40 \mathrm{Ab}$ treatment exacerbates disease, and $\alpha C D 154 \mathrm{Ab}$ and siRNA silencing of CD40 attenuates disease [83-86].

Other TNF superfamily checkpoint regulators are associated with RA. Soluble CD137 and CD137 ligand are also increased in RA patients in comparison with healthy controls, and $\alpha \mathrm{CD} 137 \mathrm{Ab}$ treatment decreases CIA severity [87-89]. In addition, $\mathrm{T}$ cells expressing CD134 accumulate in effected synovial joints of RA patients. In CIA, both $\alpha \mathrm{CD} 134 \mathrm{Ab}$ treatment and CD134-Ig treatment can attenuate disease [90-93]. This observation suggests that blocking engagement of CD134 with its ligand is responsible for this effect. CD70 is also overexpressed on $\mathrm{CD} 4^{+} \mathrm{CD} 28^{-} \mathrm{T}$ cells from RA patients, and treatment of CIA with $\alpha \mathrm{CD} 70$ Ab reduced autoantibody titers and disease severity $[94,95]$. Currently there are no clinical trials of these molecules in RA.

\section{Juvenile idiopathic arthritis}

Immune checkpoint regulators are also implicated in the pathogenesis of JIA. Patients have an increased proportion of activated $\mathrm{CD}^{+}$and $\mathrm{CD}^{+} \mathrm{T}$ cells expressing CD25 and CD69, and lacking CD28 expression. There is a concomitant decrease in the naïve T-cell pool with shortened telomere length, suggestive of premature aging of this cell population [96]. In the CD8 T-cell compartment, CD28 negative cells have enhanced CD31 expression, allowing $\mathrm{T}$ cell receptor-independent activation of these cells [97]. In comparison with healthy controls, JIA patients have reduced numbers of dendritic cells in the blood and increased numbers in the synovial fluid. The 
dendritic cells in the synovial fluid express high levels of CD80, CD86, and CD40 in comparison with those in the blood, suggesting they are actively promoting inflammation in the joint [98]. Abatacept is FDA approved for the treatment of JIA alone and in combination with methotrexate on the basis of a double-blind withdrawal study [99]. Additional potential targets in this disease are B7H4, identified as a susceptibility gene, and CD154, whose soluble levels are elevated in JIA $[100,101]$.

\section{Sjogren's syndrome}

SS is an autoimmune systemic disorder that can occur by itself or in combination with other connective tissue diseases. Clinically, SS is characterized by dry eyes and dry mouth. This results from impaired exocrine function of the lacrimal and salivary glands, respectively, due to damage from a predominantly $\mathrm{CD} 4^{+} \mathrm{T}$-cell infiltration [102]. The serologic hallmarks of SS include autoantibodies directed against ribonucleoprotein components SS-A (Ro) and/or SS-B (La) [103].

CD28 and CD152 interactions with CD80 and CD86 represent the best studied immune checkpoint regulators in SS. In SS patients, high levels of soluble CD28 are found in the serum and loss of expression on T cells is detected [26,104] and, in vitro, soluble CD28 inhibits T-cell proliferation in response to $\alpha \mathrm{CD} 3$ [26]. This is further complimented in vivo in NFS/sld mice, a model of SS where $\mathrm{CD} 4^{+} \mathrm{CD} 28^{-} \mathrm{T}$ cells in predisease mice express mRNA for IL-4, IL-10, and transforming growth factor beta, and prevent autoimmune lesion formation when adoptively transferred [105]. In SS, CD152 polymorphisms are linked to disease susceptibility and autoantibody production [106,107]. At the transcriptional level CD152 mRNA is found in salivary gland tissue, and $\alpha \mathrm{CD} 152 \mathrm{Abs}$ are detected in the serum of SS patients suggesting the presence of this protein $[28,108]$.

In addition to normal expression on antigen presenting cells, CD80 and CD86 are expressed on salivary gland epithelial cells and duct cells, and can be further upregulated in patients with sialoadentis with IFNy $[109,110]$. On duct cells, CD80 and CD86 expression is associated with Th1 cytokines (IL-2 and IFNY) and Th2 cytokines (IL-4 and IL-5), respectively [111]. This suggests that duct cells and other nonhematopoietic cells in the salivary glands express checkpoint regulator proteins that influence the development of inflammation. Therapeutically, NFS/sld mice treated with $\alpha$ CD86 Ab show reduced autoantibody production, T-cell activation, and a lack of autoimmune lesions, suggesting that the therapy eliminates CD28 co-stimulation [112]. In C57BL/6.NOD-Aec1Aec2 mice, another model for SS, treatment with an adenoassociated virus-2 vector encoding a CD152-Ig fusion protein reduced cell infiltration and Th1 and Th17 cytokine production [113], probably by binding to CD80 and CD86 and preventing co-stimulation through CD28. At present, a phase II study is currently recruiting inflammatory arthritis patients with SS to investigate the efficacy of abatacept [ClinicalTrials.gov:NCT02027298].

A few additional B7 family members have been examined in SS. For example, increased CD279 mRNA levels have been found in SS salivary gland tissue [108]. T cells in inflamed salivary glands express elevated levels of CD279, and CD274 expression on epithelial cells can be induced by IFN $\gamma$ [114]. Since expression is intact, one speculation is that signaling through this co-inhibitory molecule pair is defective, because this potent negative checkpoint regulator pathway would be expected to control inflammatory T-cell responses in such a setting. One study has found in SS patients that salivary gland epithelial cells expressing CD275 can differentiate $\mathrm{CD} 4^{+} \mathrm{T}$ cells into T-follicular helper cells [115]. In one murine model, increased cell infiltration into the salivary glands has been reported in $\mathrm{CD}_{272^{-/-}}$mice [116]. These B7 molecules therefore play a role in determining the outcome of $\mathrm{T}$-cell responses in SS and warrant further preclinical studies.

TNF superfamily members are also implicated in SS. Soluble CD154 is increased in the serum of SS patients and CD40:CD154 engagement can induce apoptosis of salivary gland cells $[117,118]$. However, treatment of nonobese diabetic mice with a vector containing CD40-Ig showed no significant reduction in inflammation in the salivary glands [119]. One study has linked CD252 polymorphisms with B-cell activation in patients with primary SS [120]. Similarly, the CD27-CD70 pathway is associated with B-cell abnormalities in SS. This association is demonstrated by the presence of $\mathrm{CD} 27^{+}$memory B cells in inflamed salivary glands [121,122] and overexpression of $\mathrm{CD} 70$ on $\mathrm{CD}^{+} \mathrm{T}$ cells due to hypomethylation of the CD70 promoter in SS patients [123].

\section{Psoriasis}

Psoriasis is a chronic inflammatory skin disease characterized by hyperproliferation of kertinocytes, affecting approximately $2 \%$ of the population [124]. Some patients also have associated psoriatic arthritis, a destructive spondyloarthropathy. Treatments for psoriasis vary considerably depending on disease severity and the presence or absence of arthritis. These treatments include topical or systemic agents such as corticosteroids, retinoids, vitamin D analogs, ultraviolet light, methotrexate, cyclosporin, TNF inhibitors, and $\alpha \mathrm{IL}-12 / 23$ (p40) [125]. Little work has been done examining the role of co-stimulatory and coinhibitory molecules during disease. However, studies with abatacept have shown that treatment can result in clinical improvement in patients with severe psoriasis and psoriatic arthritis [126-130]. In addition, elevated levels of CD154 are found on $\mathrm{T}$ cells from both psoriasis and 


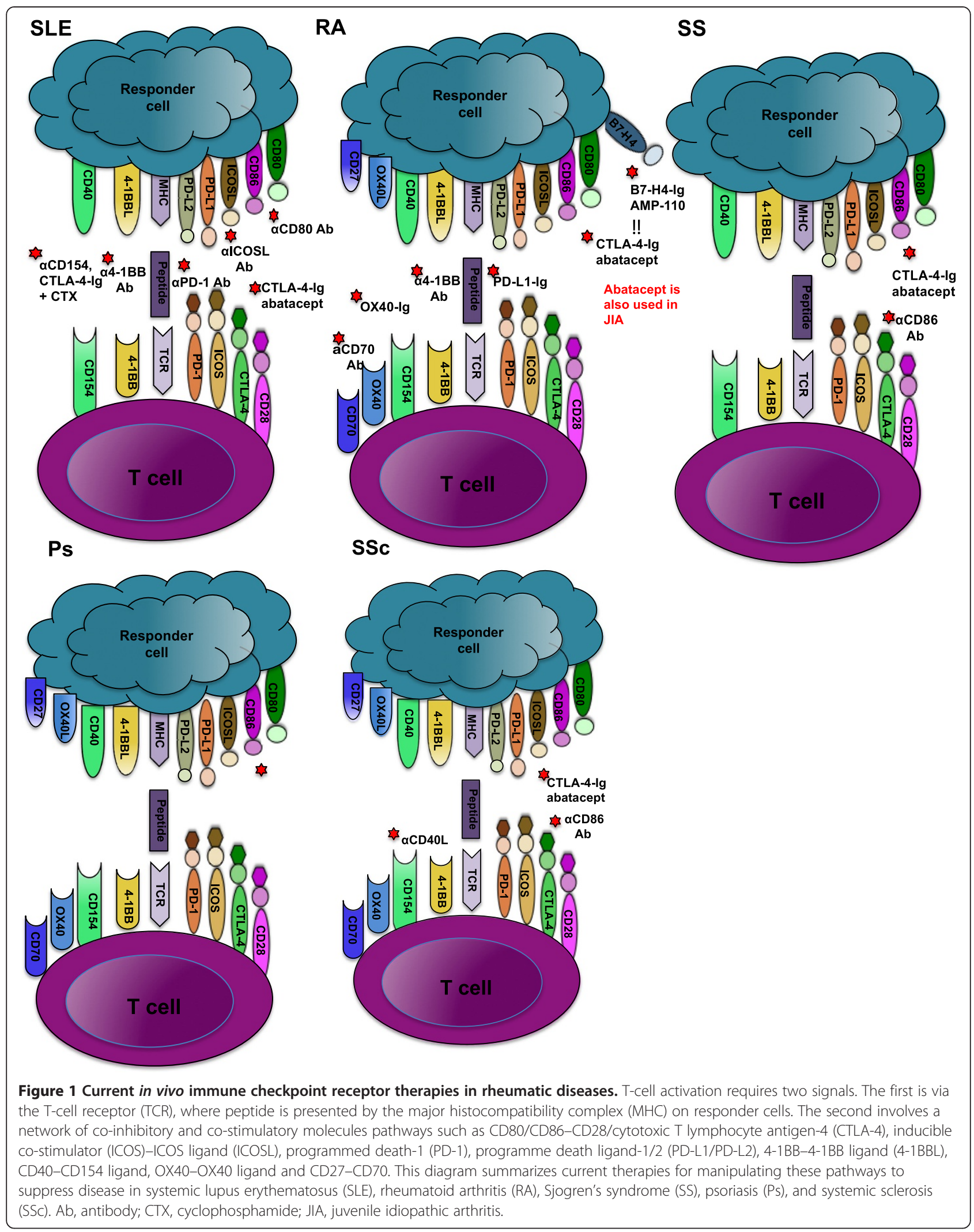


psoriatic arthritis patients, suggesting that $\alpha \mathrm{CD} 154 \mathrm{Ab}$ treatment may be effective in this disease $[131,132]$.

\section{Systemic sclerosis}

SSc is a complex autoimmune disease characterized by inflammation, vascular abnormalities, and fibrosis in the skin and internal organs and is more common in females than males. Early skin lesions demonstrate infiltration of activated $\mathrm{CD} 4^{+} \mathrm{T}$ cells, $\mathrm{CD} 8^{+} \mathrm{T}$ cells, monocytes, and macrophages [133-135]. In addition, autoantibodies are present that can directly promote fibrosis, and the pattern of antinuclear antibodies present can predict disease progression [136-138]. TNF superfamily co-stimulatory molecules have been associated with disease. Demethylation of CD154 regulatory elements in females is associated with $\mathrm{CD} 154$ overexpression on $\mathrm{CD} 4^{+} \mathrm{T}$ cells [139]. Patients also exhibit elevated plasma levels of soluble CD154. In bleomycin-induced skin sclerosis, a murine model of the disease, prophylactic $\alpha \mathrm{CD} 154 \mathrm{Ab}$ treatment attenuated disease [140]. In addition, CD70 is overexpressed in T cells from patients with SSc and this correlates with demethylation of its promoter region [141]. Gene polymorphisms in CD134 are associated with increased susceptibility to SSc [142]. These observations suggest that therapies targeting CD154, CD70, and CD134 may be worth further investigation for the treatment of disease.

\section{Conclusions}

In summary, checkpoint regulators represent viable immunotherapeutic targets for the treatment of both autoimmunity and cancer. A wealth of both mouse and human data indicate that co-stimulatory and co-inhibitory molecules are critical in a number of autoimmune rheumatic diseases (Figure 1). In addition, interventions in multiple murine models utilizing several of these pathways, either by blocking co-stimulatory receptors or by engaging inhibitory receptors, have profound therapeutic effects. However, abatacept is the only agent to achieve FDA approval in the autoimmune human diseases RA and JIA. To date, these findings have not translated into safe and effective therapy for other diseases. In light of the veritable explosion of effective treatments for RA and the approval of more agents for the treatment of psoriatic arthritis, a particular disappointment is the limited progress on this front in SLE. Expectations are still high that this will be achieved within the next few years. The current leading contenders for a successful agent in SLE from a checkpoint regulator perspective are $\alpha C D 275$, abatacept, or a modified $\alpha \mathrm{CD} 154 \mathrm{Ab}$. Perhaps SS and certainly SSc remain even more daunting disease targets. The intense ongoing investigation in this already fruitful area will undoubtedly produce more candidates for clinical trials in SLE and other rheumatic diseases in the near future.

\section{Abbreviations}

Ab: Antibody; BTLA: B and T lymphocyte attenuator; CIA: Collagen-induced arthritis; FDA: US Food and Drug Administration; GN: Glomerulonephritis; HVEM: Herpes virus entry mediator; IFN: Interferon; Ig: Immunoglobulin, IL, interleukin; JIA: Juvenile idiopathic arthritis; PD-L: Programmed death ligand; RA: Rheumatoid arthritis; SLE: Systemic lupus erythematosus; SS: Sjogren's syndrome; SSc: Systemic sclerosis; Th: T helper; TNF: Tumor necrosis factor.

\section{Competing interests}

RJN is CSO, has a commercial research grant, other commercial research support, and ownership interest (including patents), and is a consultant/ advisory board member of ImmuNext. The remaining authors declare that they have no competing interests.

\section{Acknowledgements}

This research was supported by the National Institutes of Health (R01Al098007), the Wellcome Trust (principle research fellowship to RJN), and the National Institute for Health Research Biomedical Research Centre based at Guy's and St Thomas' NHS Foundation Trust and King's College London. The views expressed are those of the authors and not necessarily those of the National Institutes of Health, the National Health Service, the National Institute for Health Research, or the Department of Health.

\section{Author details}

'Department of Microbiology and Immunology, Norris Cotton Cancer Center, Geisel School of Medicine at Dartmouth, 1 Medical Center Drive, Lebanon, $\mathrm{NH}$ 03756, USA. ${ }^{2}$ Department of Medicine, Section of Rheumatology, Dartmouth-Hitchcock Medical Center, Geisel School of Medicine at Dartmouth, 1 Medical Center Drive, Lebanon, NH 03756, USA. ${ }^{3}$ Medical Research Council Centre of Transplantation, Guy's Hospital, King's College London, London SE1 9RT, UK. ${ }^{4}$ Department of Immune Regulation and Intervention, King's College London, King's Health Partners, London SE1 9RT, UK.

Published online: 29 October 2014

\section{References}

1. Jenkins MK: The ups and downs of T cell costimulation. Immunity 1994, 1:443-446.

2. Ceeraz S, Nowak EC, Noelle RJ: B7 family checkpoint regulators in immune regulation and disease. Trends Immunol 2013, 34:556-563.

3. Brandt CS, Baratin M, Yi EC, Kennedy J, Gao Z, Fox B, Haldeman B, Ostrander CD, Kaifu T, Chabannon C, Moretta A, West R, Xu W, Vivier E, Levin SD: The B7 family member B7-H6 is a tumor cell ligand for the activating natural killer cell receptor NKp30 in humans. J Exp Med 2009, 206:1495-1503.

4. Meylan F, Richard AC, Siegel RM: TL1A and DR3, a TNF family ligand-receptor pair that promotes lymphocyte costimulation, mucosal hyperplasia, and autoimmune inflammation. Immunol Rev 2011, 244:188-196.

5. Migone TS, Zhang J, Luo X, Zhuang L, Chen C, Hu B, Hong JS, Perry JW, Chen SF, Zhou JX, Cho YH, Ullrich S, Kanakaraj P, Carrell J, Boyd E, Olsen HS, Hu G, Pukac L, Liu D, Ni J, Kim S, Gentz R, Feng P, Moore PA, Ruben SM, Wei P: TL1A is a TNF-like ligand for DR3 and TR6/DCR3 and functions as a T cell costimulator. Immunity 2002, 16:479-492.

6. Watts TH: TNF/TNFR family members in costimulation of T cell responses. Annu Rev Immunol 2005, 23:23-68.

7. Elgueta R, Benson MJ, de Vries VC, Wasiuk A, Guo Y, Noelle RJ: Molecular mechanism and function of CD40/CD40L engagement in the immune system. Immunol Rev 2009, 229:152-172.

8. Pardoll D, Drake C: Immunotherapy earns its spot in the ranks of cancer therapy. J Exp Med 2012, 209:201-209.

9. Hodi FS, O'Day SJ, McDermott DF, Weber RW, Sosman JA, Haanen JB, Gonzalez R, Robert C, Schadendorf D, Hassel JC, Akerley W, van den Eertwegh AJ, Lutzky J, Lorigan P, Vaubel JM, Linette GP, Hogg D, Ottensmeier CH, Lebbé C, Peschel C, Quirt I, Clark Jl, Wolchok JD, Weber JS, Tian J, Yellin MJ, Nichol GM, Hoos A, Urba WJ: Improved survival with ipilimumab in patients with metastatic melanoma. N Engl J Med 2010, 363:711-723.

10. Alvarez-Quiroga C, Abud-Mendoza C, Doniz-Padilla L, Juarez-Reyes A, Monsivais-Urenda A, Baranda L, Gonzalez-Amaro R: CTLA-4-Ig therapy 
diminishes the frequency but enhances the function of Treg cells in patients with rheumatoid arthritis. J Clin Immunol 2011, 31:588-595.

11. Wen Z, Xu L, Chen X, Xu W, Yin Z, Gao X, Xiong S: Autoantibody induction by DNA-containing immune complexes requires HMGB1 with the TLR2/microRNA-155 pathway. J Immunol 2013, 190:5411-5422.

12. Swigris JJ, Fischer A, Gillis J, Meehan RT, Brown KK: Pulmonary and thrombotic manifestations of systemic lupus erythematosus. Chest 2008, 133:271-280.

13. Deane KD, El-Gabalawy H: Pathogenesis and prevention of rheumatic disease: focus on preclinical RA and SLE. Nat Rev Rheumatol 2014, 10:212-228.

14. Ramos-Casals M, Soto MJ, Cuadrado MJ, Khamashta MA: Rituximab in systemic lupus erythematosus: a systematic review of off-label use in 188 cases. Lupus 2009, 18:767-776.

15. Merrill JT, Neuwelt CM, Wallace DJ, Shanahan JC, Latinis KM, Oates JC, Utset TO, Gordon C, Isenberg DA, Hsieh HJ, Zhang D, Brunetta PG: Efficacy and safety of rituximab in moderately-to-severely active systemic lupus erythematosus: the randomized, double-blind, phase II/III systemic lupus erythematosus evaluation of rituximab trial. Arthritis Rheum 2010 62:222-233

16. Eisenstein M: Approval on a knife edge. Nat Biotechnol 2012, 30:26-29.

17. Townsend MJ, Monroe JG, Chan AC: B-cell targeted therapies in human autoimmune diseases: an updated perspective. Immunol Rev 2010, 237:264-283.

18. Desai-Mehta A, Mao C, Rajagopalan S, Robinson T, Datta SK: Structure and specificity of $T$ cell receptors expressed by potentially pathogenic anti-DNA autoantibody-inducing T cells in human lupus. J Clin Invest 1995, 95:531-541.

19. Valencia X, Yarboro C, Illei G, Lipsky PE: Deficient CD4 $4^{+} \mathrm{CD} 25^{\text {high }}$ $T$ regulatory cell function in patients with active systemic lupus erythematosus. J Immunol 2007, 178:2579-2588.

20. Niewold TB, Hua J, Lehman TJ, Harley JB, Crow MK: High serum IFN-alpha activity is a heritable risk factor for systemic lupus erythematosus. Genes Immun 2007, 8:492-502.

21. Finck BK, Linsley PS, Wofsy D: Treatment of murine lupus with CTLA4Ig Science 1994, 265:1225-1227.

22. Daikh DI, Wofsy D: Cutting edge: reversal of murine lupus nephritis with CTLA4Ig and cyclophosphamide. J Immunol 2001, 166:2913-2916.

23. Wang X, Huang W, Mihara M, Sinha J, Davidson A: Mechanism of action of combined short-term CTLA4Ig and anti-CD40 ligand in murine systemic lupus erythematosus. J Immunol 2002, 168:2046-2053.

24. Schiffer L, Bethunaickan R, Ramanujam M, Huang W, Schiffer M, Tao H, Madaio MP, Bottinger EP, Davidson A: Activated renal macrophages are markers of disease onset and disease remission in lupus nephritis. $\mathrm{J}$ Immunol 2008, 180:1938-1947.

25. Merrill JT, Burgos-Vargas R, Westhovens R, Chalmers A, D'Cruz D, Wallace DJ, Bae SC, Sigal L, Becker JC, Kelly S, Raghupathi K, Li T, Peng Y, Kinaszczuk M, Nash P: The efficacy and safety of abatacept in patients with non-lifethreatening manifestations of systemic lupus erythematosus: results of a twelve-month, multicenter, exploratory, phase IIb, randomized, doubleblind, placebo-controlled trial. Arthritis Rheum 2010, 62:3077-3087.

26. Hebbar M, Jeannin P, Magistrelli G, Hatron PY, Hachulla E, Devulder B, Bonnefoy JY, Delneste $Y$ : Detection of circulating soluble CD28 in patients with systemic lupus erythematosus, primary Sjogren's syndrome and systemic sclerosis. Clin Exp Immunol 2004, 136:388-392.

27. Lee $\mathrm{YH}$, Harley JB, Nath SK: CTLA-4 polymorphisms and systemic lupus erythematosus (SLE): a meta-analysis. Hum Genet 2005, 116:361-367.

28. Matsui T, Kurokawa M, Kobata T, Oki S, Azuma M, Tohma S, Inoue T, Yamamoto K, Nishioka K, Kato T: Autoantibodies to T cell costimulatory molecules in systemic autoimmune diseases. J Immunol 1999, 162:4328-4335.

29. Shin Jl, Park SJ, Saleem MA: The beneficial effect of abatacept on lupus nephritis: the role of podocyte beta1-integrin stabilization and Tregs repopopulation? Arthritis Rheumatol 2014, 66:2913-2914.

30. Patschan S, Dolff S, Kribben A, Durig J, Patschan D, Wilde B, Specker C, Philipp T, Witzke O: CD134 expression on CD4 ${ }^{+}$T cells is associated with nephritis and disease activity in patients with systemic lupus erythematosus. Clin Exp Immunol 2006, 145:235-242.

31. Shi Q, Gao ZY, Xie F, Wang LF, Gu YP, Yang TJ, Huang L, Qian QH, Qiu YH: A novel monoclonal antibody against human CD80 and its immune protection in a mouse lupus-like disease. Int J Immunopathol Pharmacol 2011, 24:583-593.
32. Hutloff A, Buchner K, Reiter K, Baelde HJ, Odendahl M, Jacobi A, Dorner T, Kroczek RA: Involvement of inducible costimulator in the exaggerated memory B cell and plasma cell generation in systemic lupus erythematosus. Arthritis Rheum 2004, 50:3211-3220.

33. Her M, Kim D, Oh M, Jeong H, Choi I: Increased expression of soluble inducible costimulator ligand (ICOSL) in patients with systemic lupus erythematosus. Lupus 2009, 18:501-507.

34. Yang JH, Zhang J, Cai Q, Zhao DB, Wang J, Guo PE, Liu L, Han XH, Shen Q: Expression and function of inducible costimulator on peripheral blood $\mathrm{T}$ cells in patients with systemic lupus erythematosus. Rheumatology (Oxford) 2005, 44:1245-1254.

35. Tada Y, Koarada S, Tomiyoshi Y, Morito F, Mitamura M, Haruta Y, Ohta A, Nagasawa K: Role of inducible costimulator in the development of lupus in MRL/Ipr mice. Clin Immunol 2006, 120:179-188.

36. Iwai H, Abe M, Hirose S, Tsushima F, Tezuka K, Akiba H, Yagita H, Okumura K, Kohsaka H, Miyasaka N, Azuma M: Involvement of inducible costimulator-B7 homologous protein costimulatory pathway in murine lupus nephritis. J Immunol 2003, 171:2848-2854.

37. Keir ME, Butte MJ, Freeman GJ, Sharpe AH: PD-1 and its ligands in tolerance and immunity. Annu Rev Immunol 2008, 26:677-704.

38. Prokunina L, Castillejo-Lopez C, Oberg F, Gunnarsson I, Berg L, Magnusson V, Brookes AJ, Tentler D, Kristjansdottir H, Grondal G, Bolstad Al, Svenungsson E, Lundberg I, Sturfelt G, Jönssen A, Truedsson L, Lima G, Alcocer-Varela J, Jonsson R, Gyllensten UB, Harley JB, Alarcón-Segovia D, Steinsson K, Alarcón-Riquelme ME: A regulatory polymorphism in PDCD1 is associated with susceptibility to systemic lupus erythematosus in humans. Nat Genet 2002, 32:666-669.

39. Nishimura H, Nose M, Hiai H, Minato N, Honjo T: Development of lupus-like autoimmune diseases by disruption of the PD-1 gene encoding an ITIM motif-carrying immunoreceptor. Immunity 1999, 11:141-151.

40. Kasagi S, Kawano S, Okazaki T, Honjo T, Morinobu A, Hatachi S, Shimatani K, Tanaka Y, Minato N, Kumagai S: Anti-programmed cell death 1 antibody reduces $\mathrm{CD} 4^{+} \mathrm{PD}-1^{+} \mathrm{T}$ cells and relieves the lupus-like nephritis of NZB/ W F1 mice. J Immunol 2010, 184:2337-2347.

41. Wong M, La Cava A, Hahn BH: Blockade of programmed death-1 in young (New Zealand Black $\times$ New Zealand White) F1 mice promotes the suppressive capacity of $\mathrm{CD}^{+}$regulatory $\mathrm{T}$ cells protecting from lupus-like disease. J Immunol 2013, 190:5402-5410.

42. Wong M, La Cava A, Singh RP, Hahn BH: Blockade of programmed death-1 in young (New Zealand black $\times$ New Zealand white) F1 mice promotes the activity of suppressive $\mathrm{CD} 8^{+} \mathrm{T}$ cells that protect from lupus-like disease. J Immunol 2010, 185:6563-6571.

43. Mehta J, Genin A, Brunner M, Scalzi LV, Mishra N, Beukelman T, Cron RQ: Prolonged expression of CD154 on CD4 T cells from pediatric lupus patients correlates with increased CD154 transcription, increased nuclear factor of activated T cell activity, and glomerulonephritis. Arthritis Rheum 2010, 62:2499-2509.

44. Desai-Mehta A, Lu L, Ramsey-Goldman R, Datta SK: Hyperexpression of CD40 ligand by $B$ and $T$ cells in human lupus and its role in pathogenic autoantibody production. J Clin Invest 1996, 97:2063-2073.

45. Koshy M, Berger D, Crow MK: Increased expression of CD40 ligand on systemic lupus erythematosus lymphocytes. J Clin Invest 1996, 98:826-837.

46. Kato K, Santana-Sahagun E, Rassenti LZ, Weisman MH, Tamura N, Kobayashi S, Hashimoto H, Kipps TJ: The soluble CD40 ligand sCD154 in systemic lupus erythematosus. J Clin Invest 1999, 104:947-955.

47. Early GS, Zhao W, Burns CM: Anti-CD40 ligand antibody treatment prevents the development of lupus-like nephritis in a subset of New Zealand black $\times$ New Zealand white mice. Response correlates with the absence of an anti-antibody response. J Immunol 1996, 157:3159-3164.

48. Quezada SA, Eckert M, Adeyi OA, Schned AR, Noelle RJ, Burns CM: Distinct mechanisms of action of anti-CD154 in early versus late treatment of murine lupus nephritis. Arthritis Rheum 2003, 48:2541-2554.

49. Kalunian KC, Davis JC Jr, Merrill JT, Totoritis MC, Wofsy D, IDEC-131 Lupus Study Group: Treatment of systemic lupus erythematosus by inhibition of T cell costimulation with anti-CD154: a randomized, double-blind, placebo-controlled trial. Arthritis Rheum 2002, 46:3251-3258.

50. Grammer AC, Slota R, Fischer R, Gur H, Girschick H, Yarboro C, Illei GG, Lipsky PE: Abnormal germinal center reactions in systemic lupus erythematosus demonstrated by blockade of CD154-CD40 interactions. J Clin Invest 2003, 112:1506-1520. 
51. Boumpas DT, Furie R, Manzi S, Illei GG, Wallace DJ, Balow JE, Vaishnaw A, BG9588 Lupus Nephritis Trial Group: A short course of BG9588 (anti-CD40 ligand antibody) improves serologic activity and decreases hematuria in patients with proliferative lupus glomerulonephritis. Arthritis Rheum 2003, 48:719-727.

52. Hausding $M$, Jurk K, Daub S, Kroller-Schon S, Stein J, Schwenk M, Oelze M, Mikhed Y, Kerahrodi JG, Kossmann S, Jansen T, Schulz E, Wenzel P, Reske-Kunz AB, Becker C, Munzel T, Grabbe S, Daiber A: CD40L contributes to angiotensin II-induced pro-thrombotic state, vascular inflammation, oxidative stress and endothelial dysfunction. Basic Res Cardiol 2013, 108:386.

53. Xie JH, Yamniuk AP, Borowski V, Kuhn R, Susulic V, Rex-Rabe S, Yang X, Zhou X, Zhang Y, Gillooly K, Brosius R, Ravishankar R, Waggie K, Mink K, Price L, Rehfuss R, Tamura J, An Y, Cheng L, Abramczyk B, Ignatovich O, Drew P, Grant S, Bryson JW, Suchard S, Salter-Cid L, Nadler S, Suri A: Engineering of a novel anti-CD40L domain antibody for treatment of autoimmune diseases. J Immunol 2014, 192:4083-4092.

54. Aten J, Roos A, Claessen N, Schilder-Tol EJ, Ten Berge IJ, Weening JJ: Strong and selective glomerular localization of CD134 ligand and TNF receptor-1 in proliferative lupus nephritis. J Am Soc Nephrol 2000, 11:1426-1438.

55. Zhou YB, Ye RG, Li YJ, Xie CM, Wu YH: Effect of anti-CD134L mAb and CTLA4Ig on ConA-induced proliferation, Th cytokine secretion, and anti-dsDNA antibody production in spleen cells from lupus-prone BXSB mice. Autoimmunity 2008, 41:395-404.

56. Zhou YB, Ye RG, Li YJ, Xie CM: Targeting the CD134-CD134L interaction using anti-CD134 and/or rhCD134 fusion protein as a possible strategy to prevent lupus nephritis. Rheumatol Int 2009, 29:417-425.

57. Richardson B, Scheinbart L, Strahler J, Gross L, Hanash S, Johnson M: Evidence for impaired T cell DNA methylation in systemic lupus erythematosus and rheumatoid arthritis. Arthritis Rheum 1990, 33:1665-1673.

58. Wei C, Anolik J, Cappione A, Zheng B, Pugh-Bernard A, Brooks J, Lee EH, Milner EC, Sanz I: A new population of cells lacking expression of CD27 represents a notable component of the B cell memory compartment in systemic lupus erythematosus. J Immunol 2007, 178:6624-6633.

59. Jacobi AM, Odendahl M, Reiter K, Bruns A, Burmester GR, Radbruch A, Valet G, Lipsky PE, Dorner T: Correlation between circulating CD27high plasma cells and disease activity in patients with systemic lupus erythematosus. Arthritis Rheum 2003, 48:1332-1342.

60. Vinay DS, Kim JD, Asai T, Choi BK, Kwon BS: Absence of 4 1BB gene function exacerbates lacrimal gland inflammation in autoimmune-prone MRL-Faslpr mice. Invest Ophthalmol Vis Sci 2007, 48:4608-4615.

61. Sun Y, Chen HM, Subudhi SK, Chen J, Koka R, Chen L, Fu YX: Costimulatory molecule-targeted antibody therapy of a spontaneous autoimmune disease. Nat Med 2002, 8:1405-1413.

62. Foell J, Strahotin S, O'Neil SP, McCausland MM, Suwyn C, Haber M, Chander PN, Bapat AS, Yan XJ, Chiorazzi N, Hoffmann MK, Mittler RS: CD137 costimulatory $T$ cell receptor engagement reverses acute disease in lupus-prone NZB $x$ NZW F1 mice. J Clin Invest 2003, 111:1505-1518.

63. Cross M, Smith E, Hoy D, Carmona L, Wolfe F, Vos T, Williams B, Gabriel S, Lassere M, Johns N, Buchbinder R, Woolf A, March L: The global burden of rheumatoid arthritis: estimates from the Global Burden of Disease 2010 study. Ann Rheum Dis 2014, 73:1316-1322.

64. Plenge RM, Padyukov L, Remmers EF, Purcell S, Lee AT, Karlson EW, Wolfe F, Kastner DL, Alfredsson L, Altshuler D, Gregersen PK, Klareskog L, Rioux JD: Replication of putative candidate-gene associations with rheumatoid arthritis in $>4,000$ samples from North America and Sweden: association of susceptibility with PTPN22, CTLA4, and PADI4. Am J Hum Genet 2005, 77:1044-1060

65. Flores-Borja F, Jury EC, Mauri C, Ehrenstein MR: Defects in CTLA-4 are associated with abnormal regulatory $\mathrm{T}$ cell function in rheumatoid arthritis. Proc Natl Acad Sci U S A 2008, 105:19396-19401.

66. Cao J, Zou L, Luo P, Chen P, Zhang L: Increased production of circulating soluble co-stimulatory molecules CTLA-4, CD28 and CD80 in patients with rheumatoid arthritis. Int Immunopharmacol 2012, 14:585-592.

67. Scarsi M, Ziglioli T, Airo P: Baseline numbers of circulating CD28-negative T cells may predict clinical response to abatacept in patients with rheumatoid arthritis. J Rheumato/ 2011, 38:2105-2111.

68. Gomez-Garcia L, Ramirez-Assad C, Vargas A, Masso F, Sanchez-Munoz F, Marquez-Velasco R, Amezcua-Guerra LM, Bojalil R: Reduced numbers of circulating CD28-negative CD4 ${ }^{+}$cells in patients with rheumatoid arthritis chronically treated with abatacept. Int J Rheum Dis 2013, 16:469-471.
69. Kong EK, Prokunina-Olsson L, Wong WH, Lau CS, Chan TM, Alarcon-Riquelme M, Lau YL: A new haplotype of PDCD1 is associated with rheumatoid arthritis in Hong Kong Chinese. Arthritis Rheum 2005, 52:1058-1062.

70. Li S, Liao W, Chen M, Shan S, Song Y, Zhang S, Song H, Yuan Z: Expression of programmed death-1 (PD-1) on $\mathrm{CD}^{+}$and $\mathrm{CD}^{+} \mathrm{T}$ cells in rheumatoid arthritis. Inflammation 2014, 37:116-121.

71. Raptopoulou AP, Bertsias G, Makrygiannakis D, Verginis P, Kritikos I, Tzardi M, Klareskog L, Catrina Al, Sidiropoulos P, Boumpas DT: The programmed death 1 /programmed death ligand 1 inhibitory pathway is up-regulated in rheumatoid synovium and regulates peripheral $\mathrm{T}$ cell responses in human and murine arthritis. Arthritis Rheum 2010, 62:1870-1880.

72. Hamel KM, Cao Y, Wang Y, Rodeghero R, Kobezda T, Chen L, Finnegan A: B7-H1 expression on non-B and non-T cells promotes distinct effects on T- and B-cell responses in autoimmune arthritis. Eur J Immunol 2010, 40:3117-3127

73. Wang G, Hu P, Yang J, Shen G, Wu X: The effects of PDL-Ig on collageninduced arthritis. Rheumatol Int 2011, 31:513-519.

74. Kamimura Y, Kobori H, Piao J, Hashiguchi M, Matsumoto K, Hirose S, Azuma M: Possible involvement of soluble B7-H4 in T cell-mediated inflammatory immune responses. Biochem Biophys Res Commun 2009, 389:349-353.

75. Azuma T, Zhu G, Xu H, Rietz AC, Drake CG, Matteson EL, Chen L: Potential role of decoy B7-H4 in the pathogenesis of rheumatoid arthritis: a mouse model informed by clinical data. PLoS Med 2009, 6:e1000166.

76. Shang Y, Guo G, Cui Q, Li J, Ruan Z, Chen Y: The expression and anatomical distribution of BTLA and its ligand HVEM in rheumatoid synovium. Inflammation 2012, 35:1102-1112.

77. Guo G, Shang Y, Zhu G, Bao X, Xu S, Chen Y: The expression and distribution of immunomodulatory proteins B7-H1, B7-DC, B7-H3, and B7-H4 in rheumatoid synovium. Clin Rheumatol 2012, 31:271-281.

78. Pierer M, Schulz A, Rossol M, Kendzia E, Kyburz D, Haentzschel H, Baerwald $C$, Wagner $U$ : Herpesvirus entry mediator-lg treatment during immunization aggravates rheumatoid arthritis in the collagen-induced arthritis model. J Immunol 2009, 182:3139-3145.

79. Garcia-Bermudez M, Gonzalez-Juanatey C, Lopez-Mejias R, Teruel M, Corrales A, Miranda-Filloy JA, Castaneda S, Balsa A, Fernandez-Gutierrez B, Gonzalez-Alvaro I, omez-Vaquero C, Blanco R, Llorca J, Martin J, Gonzalez-Gay MA: Study of association of CD40-CD154 gene polymorphisms with disease susceptibility and cardiovascular risk in Spanish rheumatoid arthritis patients. PLOS One 2012, 7:e49214.

80. MacDonald KP, Nishioka Y, Lipsky PE, Thomas R: Functional CD40 ligand is expressed by T cells in rheumatoid arthritis. J Clin Invest 1997, 100:2404-2414

81. Tamura N, Kobayashi S, Kato K, Bando H, Haruta K, Oyanagi M, Kuriyama M Kipps TJ, Hashimoto H: Soluble CD154 in rheumatoid arthritis: elevated plasma levels in cases with vasculitis. J Rheumatol 2001, 28:2583-2590.

82. Liao J, Liang G, Xie S, Zhao H, Zuo X, Li F, Chen J, Zhao M, Chan TM, Lu Q: CD40L demethylation in CD4 (+) T cells from women with rheumatoid arthritis. Clin Immunol 2012, 145:13-18.

83. Kyburz D, Carson DA, Corr M: The role of CD40 ligand and tumor necrosis factor alpha signaling in the transgenic $\mathrm{K} / \mathrm{BxN}$ mouse model of rheumatoid arthritis. Arthritis Rheum 2000, 43:2571-2577.

84. Tellander AC, Michaelsson E, Brunmark C, Andersson M: Potent adjuvant effect by anti-CD40 in collagen-induced arthritis. Enhanced disease is accompanied by increased production of collagen type-II reactive lgG2a and IFN-gamma. J Autoimmun 2000, 14:295-302.

85. Andreakos E, Rauchhaus U, Stavropoulos A, Endert G, Wendisch V, Benahmed AS, Giaglis S, Karras J, Lee S, Gaus H, Bennett CF, Williams RO, Sideras P, Panzner S: Amphoteric liposomes enable systemic antigen-presenting cell-directed delivery of CD40 antisense and are therapeutically effective in experimental arthritis. Arthritis Rheum 2009, 60:994-1005.

86. Zheng $X$, Suzuki $M$, Zhang $X$, Ichim TE, Zhu F, Ling H, Shunnar A, Wang MH, Garcia B, Inman RD, Min WP: RNAi-mediated CD40-CD154 interruption promotes tolerance in autoimmune arthritis. Arthritis Res Ther 2010, 12:R13.

87. Michel J, Langstein J, Hofstadter F, Schwarz H: A soluble form of CD137 (ILA/4-1BB), a member of the TNF receptor family, is released by activated lymphocytes and is detectable in sera of patients with rheumatoid arthritis. Eur J Immunol 1998, 28:290-295.

88. Foell JL, Diez-Mendiondo Bl, Diez OH, Holzer U, Ruck P, Bapat AS, Hoffmann MK, Mittler RS, Dannecker GE: Engagement of the CD137 (4-1BB) costimulatory molecule inhibits and reverses the autoimmune process in collagen-induced arthritis and establishes lasting disease resistance. Immunology 2004, 113:89-98. 
89. Seo SK, Choi JH, Kim YH, Kang WJ, Park HY, Suh JH, Choi BK, Vinay DS, Kwon BS: 4-1BB-mediated immunotherapy of rheumatoid arthritis. Nat Med 2004, 10:1088-1094

90. Brugnoni D, Bettinardi A, Malacarne F, Airo P, Cattaneo R: CD134/OX40 expression by synovial fluid $\mathrm{CD}^{+} \mathrm{T}$ lymphocytes in chronic synovitis. Br J Rheumatol 1998, 37:584-585.

91. Passacantando A, Parzanese I, Rascente M, Petrucci C, Minisola G, Tonietti G: Synovial fluid OX40T lymphocytes of patients with rheumatoid arthritis display a Th2/Th0 polarization. Int J Immunopathol Pharmacol 2006, 19:499-505.

92. Boot EP, Koning GA, Storm G, Wagenaar-Hilbers JP, van Eden W, Everse LA, Wauben MH: CD134 as target for specific drug delivery to auto-aggressive $\mathrm{CD} 4^{+} \mathrm{T}$ cells in adjuvant arthritis. Arthritis Res Ther 2005, 7:R604-R615.

93. Findlay EG, Danks L, Madden J, Cavanagh MM, McNammee K, McCann F, Snelgrove RJ, Shaw S, Feldmann M, Taylor PC, Horwood NJ, Hussell T: OX40L blockade is therapeutic in arthritis, despite promoting osteoclastogenesis. Proc Natl Acad Sci U S A 2014, 111:2289-2294.

94. Lee WW, Yang ZZ, Li G, Weyand CM, Goronzy JJ: Unchecked CD70 expression on $\mathrm{T}$ cells lowers threshold for $\mathrm{T}$ cell activation in rheumatoid arthritis. J Immunol 2007, 179:2609-2615.

95. Oflazoglu E, Boursalian TE, Zeng W, Edwards AC, Duniho S, McEarchern JA, Law CL, Gerber HP, Grewal IS: Blocking of CD27-CD70 pathway by anti-CD70 antibody ameliorates joint disease in murine collagen-induced arthritis. J Immunol 2009, 183:3770-3777.

96. Almanzar G, Zlamy M, Koppelstaetter C, Brunner A, Jeller V, Duftner C, Dejaco C, Brunner J, Prelog M: Increased replication of $\mathrm{CD}^{+}$naive T cells and changes in $\mathrm{T}$ cell homeostasis in a case of acute exacerbation of juvenile idiopathic arthritis: a case comparison study. J Med Case Rep 2013, 7:135

97. Dvergsten JA, Mueller RG, Griffin P, Abedin S, Pishko A, Michel JJ, Rosenkranz ME, Reed AM, Kietz DA, Vallejo AN: Premature cell senescence and $\mathrm{T}$ cell receptor-independent activation of $\mathrm{CD} 8^{+} \mathrm{T}$ cells in juvenile idiopathic arthritis. Arthritis Rheum 2013, 65:2201-2210.

98. Smolewska E, Stanczyk J, Brozik H, Biernacka-Zielinska M, Cebula B, Robak T, Smolewski P: Distribution and clinical significance of blood dendritic cells in children with juvenile idiopathic arthritis. Ann Rheum Dis 2008, 67:762-768.

99. Goldzweig O, Hashkes PJ: Abatacept in the treatment of polyarticular JIA: development, clinical utility, and place in therapy. Drug Des Devel Ther 2011, 5:61-70.

100. Albers HM, Reinards TH, Brinkman DM, Kamphuis SS, van Rossum MA, Hoppenreijs EP, Girschick HJ, Wouters C, Saurenmann RK, Bakker E, Verduijn W, Slagboom P, Huizinga TW, Toes RE, Houwing-Duistermaat JJ, ten Cate R, Schilham MW: Genetic variation in VTCN1 (B7-H4) is associated with course of disease in juvenile idiopathic arthritis. Ann Rheum Dis 2014, 73:1198-1201.

101. Prahalad S, Martins TB, Tebo AE, Whiting A, Clifford B, Zeft AS, McNally B, Bohnsack JF, Hill HR: Elevated serum levels of soluble CD154 in children with juvenile idiopathic arthritis. Pediatr Rheumatol Online J 2008, 6:8.

102. Bolstad Al, Jonsson R: Genetic aspects of Sjogren's syndrome. Arthritis Res 2002, 4:353-359.

103. Gordon TP, Bolstad Al, Rischmueller M, Jonsson R, Waterman SA: Autoantibodies in primary Sjogren's syndrome: new insights into mechanisms of autoantibody diversification and disease pathogenesis. Autoimmunity 2001, 34:123-132.

104. Smolenska Z, Pawlowska J, Zdrojewski Z, Daca A, Bryl E: Increased percentage of $C D 8^{+} C D 28^{-} T$ cells correlates with clinical activity in primary Sjogren's syndrome. Cell Immunol 2012, 278:143-151.

105. Saegusa K, Ishimaru N, Yanagi K, Haneji N, Nishino M, Azuma M, Saito I, Hayashi Y: Autoantigen-specific $\mathrm{CD} 4^{+} \mathrm{CD} 28^{\text {low }} \mathrm{T}$ cell subset prevents autoimmune exocrinopathy in murine Sjogren's syndrome. J Immunol 2000, 165:2251-2257.

106. Downie-Doyle S, Bayat N, Rischmueller M, Lester S: Influence of CTLA4 haplotypes on susceptibility and some extraglandular manifestations in primary Sjogren's syndrome. Arthritis Rheum 2006, 54:2434-2440.

107. Gottenberg JE, Loiseau P, Azarian M, Chen C, Cagnard N, Hachulla E, Puechal X, Sibilia J, Charron D, Mariette X, Miceli-Richard C: CTLA-4 + 49A/G and CT60 gene polymorphisms in primary Sjogren syndrome. Arthritis Res Ther 2007, 9:R24.

108. Bolstad Al, Eiken HG, Rosenlund B, Alarcon-Riquelme ME, Jonsson R: Increased salivary gland tissue expression of Fas, Fas ligand, cytotoxic T lymphocyte-associated antigen 4, and programmed cell death 1 in primary Sjogren's syndrome. Arthritis Rheum 2003, 48:174-185.

109. Manoussakis MN, Dimitriou ID, Kapsogeorgou EK, Xanthou G, Paikos S, Polihronis M, Moutsopoulos HM: Expression of B7 costimulatory molecules by salivary gland epithelial cells in patients with Sjogren's syndrome. Arthritis Rheum 1999, 42:229-239.

110. Matsumura R, Umemiya K, Goto T, Nakazawa T, Kagami M, Tomioka H, Tanabe E, Sugiyama T, Sueishi M: Glandular and extraglandular expression of costimulatory molecules in patients with Sjogren's syndrome. Ann Rheum Dis 2001, 60:473-482.

111. Tsunawaki S, Nakamura S, Ohyama Y, Sasaki M, Ikebe-Hiroki A, Hiraki A, Kadena T, Kawamura E, Kumamaru W, Shinohara M, Shirasuna K: Possible function of salivary gland epithelial cells as nonprofessional antigenpresenting cells in the development of Sjogren's syndrome. J Rheumatol 2002, 29:1884-1896.

112. Saegusa K, Ishimaru N, Yanagi K, Haneji N, Nishino M, Azuma M, Saito I, Hayashi Y: Treatment with anti-CD86 costimulatory molecule prevents the autoimmune lesions in murine Sjogren's syndrome (SS) through up-regulated Th2 response. Clin Exp Immunol 2000, 119:354-360.

113. Yin $H$, Nguyen $C Q$, Samuni $Y$, Uede T, Peck AB, Chiorini JA: Local delivery of AAV2-CTLA4lgG decreases sialadenitis and improves gland function in the C57BL/6NOD-Aec1Aec2 mouse model of Sjogren's syndrome. Arthritis Res Ther 2012, 14:R40.

114. Kobayashi M, Kawano S, Hatachi S, Kurimoto C, Okazaki T, Iwai Y, Honjo T, Tanaka Y, Minato N, Komori T, Maeda S, Kumagai S: Enhanced expression of programmed death-1 (PD-1)/PD-L1 in salivary glands of patients with Sjogren's syndrome. J Rheumatol 2005, 32:2156-2163.

115. Gong YZ, Nititham J, Taylor K, Miceli-Richard C, Sordet C, Wachsmann D, Bahram S, Georgel P, Criswell LA, Sibilia J, Mariette X, Alsaleh G, Gottenberg JE: Differentiation of follicular helper T cells by salivary gland epithelial cells in primary Sjogren's syndrome. J Autoimmun 2014, 51:57-66.

116. Oya Y, Watanabe N, Owada T, Oki M, Hirose K, Suto A, Kagami S, Nakajima H, Kishimoto T, Iwamoto I, Murphy TL, Murphy KM, Saito Y: Development of autoimmune hepatitis-like disease and production of autoantibodies to nuclear antigens in mice lacking $B$ and $T$ lymphocyte attenuator. Arthritis Rheum 2008, 58:2498-2510.

117. Goules A, Tzioufas AG, Manousakis MN, Kirou KA, Crow MK, Routsias JG: Elevated levels of soluble CD40 ligand (sCD40L) in serum of patients with systemic autoimmune diseases. J Autoimmun 2006, 26:165-171.

118. Ping L, Ogawa N, Zhang Y, Sugai S, Masaki Y, Weiguo X: p38 mitogenactivated protein kinase and nuclear factor-kappaB facilitate CD40mediated salivary epithelial cell death. J Rheumatol 2012, 39:1256-1264.

119. Roescher N, Vosters JL, Lai Z, Uede T, Tak PP, Chiorini JA: Local administration of soluble CD40:Fc to the salivary glands of non-obese diabetic mice does not ameliorate autoimmune inflammation. PLoS One 2012, 7:e51375.

120. Nordmark G, Kristjansdottir G, Theander E, Appel S, Eriksson P, Vasaitis L, Kvarnstrom M, Delaleu N, Lundmark P, Lundmark A, Sjowall C, Brun JG, Jonsson MV, Harboe E, Goransson LG, Johnsen SJ, Soderkvist P, Eloranta ML, Alm G, Baecklund E, Wahren-Herlenius M, Omdal R, Ronnblom L, Jonsson R, Syvanen AC: Association of EBF1, FAM167A (C8orf13)-BLK and TNFSF4 gene variants with primary Sjogren's syndrome. Genes Immun 2011, 12:100-109.

121. Hansen A, Odendahl M, Reiter K, Jacobi AM, Feist E, Scholze J, Burmester GR, Lipsky PE, Dorner T: Diminished peripheral blood memory B cells and accumulation of memory $B$ cells in the salivary glands of patients with Sjogren's syndrome. Arthritis Rheum 2002, 46:2160-2171.

122. Hansen A, Gosemann M, Pruss A, Reiter K, Ruzickova S, Lipsky PE, Dorner T: Abnormalities in peripheral $B$ cell memory of patients with primary Sjogren's syndrome. Arthritis Rheum 2004, 50:1897-1908.

123. Yin H, Zhao M, Wu X, Gao F, Luo Y, Ma L, Liu S, Zhang G, Chen J, Li F, Zuo $X$, Lu Q: Hypomethylation and overexpression of CD70 (TNFSF7) in CD4 ${ }^{+}$ T cells of patients with primary Sjogren's syndrome. J Dermatol Sci 2010, 59:198-203.

124. Nestle FO, Kaplan DH, Barker J: Psoriasis. N Engl J Med 2009, 361:496-509.

125. Rahman M, Alam K, Ahmad MZ, Gupta G, Afzal M, Akhter S, Kazmi I, Jyoti, Ahmad FJ, Anwar F: Classical to current approach for treatment of psoriasis: a review. Endocr Metab Immune Disord Drug Targets 2012, 12:287-302

126. Abrams JR, Lebwohl MG, Guzzo CA, Jegasothy BV, Goldfarb MT, Goffe BS, Menter A, Lowe NJ, Krueger G, Brown MJ, Weiner RS, Birkhofer MJ, Warner 
GL, Berry KK, Linsley PS, Krueger JG, Ochs HD, Kelley SL, Kang S: CTLA4Igmediated blockade of T-cell costimulation in patients with psoriasis vulgaris. J Clin Invest 1999, 103:1243-1252.

127. Abrams JR, Kelley SL, Hayes E, Kikuchi T, Brown MJ, Kang S, Lebwohl MG, Guzzo CA, Jegasothy BV, Linsley PS, Krueger JG: Blockade of T lymphocyte costimulation with cytotoxic T lymphocyte-associated antigen 4-immunoglobulin (CTLA4lg) reverses the cellular pathology of psoriatic plaques, including the activation of keratinocytes, dendritic cells, and endothelial cells. J Exp Med 2000, 192:681-694.

128. Mease P, Genovese MC, Gladstein G, Kivitz AJ, Ritchlin C, Tak PP, Wollenhaupt J, Bahary O, Becker JC, Kelly S, Sigal L, Teng J, Gladman D: Abatacept in the treatment of patients with psoriatic arthritis: results of a six-month, multicenter, randomized, double-blind, placebo-controlled, phase II trial. Arthritis Rheum 2011, 63:939-948.

129. Altmeyer MD, Kerisit KG, Boh EE: Therapeutic hotline. Abatacept: our experience of use in two patients with refractory psoriasis and psoriatic arthritis. Dermatol Ther 2011, 24:287-290.

130. Ursini F, Naty S, Russo E, Grembiale RD: Abatacept in psoriatic arthritis: case report and short review. J Pharmacol Pharmacother 2013, 4:S29-S32.

131. Ohta Y, Hamada Y: In situ expression of CD40 and CD40 ligand in psoriasis. Dermatology 2004, 209:21-28.

132. Daoussis D, Antonopoulos I, Andonopoulos AP, Liossis SN: Increased expression of CD154 (CD40L) on stimulated T-cells from patients with psoriatic arthritis. Rheumatology (Oxford) 2007, 46:227-231.

133. Fleischmajer R, Perlish JS, Reeves JR: Cellular infiltrates in scleroderma skin. Arthritis Rheum 1977, 20:975-984.

134. Prescott RJ, Freemont AJ, Jones CJ, Hoyland J, Fielding P: Sequential dermal microvascular and perivascular changes in the development of scleroderma. J Pathol 1992, 166:255-263.

135. Roumm AD, Whiteside TL, Medsger TA Jr, Rodnan GP: Lymphocytes in the skin of patients with progressive systemic sclerosis. Quantification, subtyping, and clinical correlations. Arthritis Rheum 1984, 27:645-653.

136. Hamaguchi Y: Autoantibody profiles in systemic sclerosis: predictive value for clinical evaluation and prognosis. J Dermatol 2010, 37:42-53.

137. Fineschi S, Cozzi F, Burger D, Dayer JM, Meroni PL, Chizzolini C: Antifibroblast antibodies detected by cell-based ELISA in systemic sclerosis enhance the collagenolytic activity and matrix metalloproteinase-1 production in dermal fibroblasts. Rheumatology (Oxford) 2007, 46:1779-1785.

138. Fineschi S, Goffin L, Rezzonico R, Cozzi F, Dayer JM, Meroni PL, Chizzolini C: Antifibroblast antibodies in systemic sclerosis induce fibroblasts to produce profibrotic chemokines, with partial exploitation of toll-like receptor 4. Arthritis Rheum 2008, 58:3913-3923.

139. Lian X, Xiao R, Hu X, Kanekura T, Jiang H, Li Y, Wang Y, Yang Y, Zhao M, LU Q: DNA demethylation of CD40l in $\mathrm{CD}^{+}{ }^{+} \mathrm{T}$ cells from women with systemic sclerosis: a possible explanation for female susceptibility. Arthritis Rheum 2012, 64:2338-2345.

140. Kawai M, Masuda A, Kuwana M: A CD40-CD154 interaction in tissue fibrosis. Arthritis Rheum 2008, 58:3562-3573.

141. Jiang H, Xiao R, Lian X, Kanekura T, Luo Y, Yin Y, Zhang G, Yang Y, Wang Y, Zhao M, Lu Q: Demethylation of TNFSF7 contributes to CD70 overexpression in $\mathrm{CD}^{+} \mathrm{T}$ cells from patients with systemic sclerosis. Clin Immunol 2012, 143:39-44.

142. Gourh P, Arnett FC, Tan FK, Assassi S, Divecha D, Paz G, McNearney T, Draeger H, Reveille JD, Mayes MD, Agarwal SK: Association of TNFSF4 (OX40L) polymorphisms with susceptibility to systemic sclerosis. Ann Rheum Dis 2010, 69:550-555.

doi:10.1186/s13075-014-0469-1

Cite this article as: Ceeraz et al.: Immune checkpoint receptors in regulating immune reactivity in rheumatic disease. Arthritis Research \& Therapy 2014 16:469. 